Wilson, F. (2015) Making loan decisions in banks: straight from the gut? Journal of Business Ethics.

Copyright (C) 2015 Springer Science+Business Media Dordrecht

A copy can be downloaded for personal non-commercial research or study, without prior permission or charge

Content must not be changed in any way or reproduced in any format or medium without the formal permission of the copyright holder(s)

When referring to this work, full bibliographic details must be given

http://eprints.gla.ac.uk/100955

Deposited on: 30 March 2015

Enlighten - Research publications by members of the University of Glasgow http://eprints.gla.ac.uk 


\section{MAKING LOAN DECISIONS IN BANKS - STRAIGHT FROM THE GUT?}

Fiona Wilson

A dam Smith B usiness School

University of Glasgow, G 12 8QQ

\section{Introduction}

The number of small businesses using a bank loan or overdraft has fallen in recent years. A round a third of businesses are finding it difficult to access money from banks (FSB , 2012). Confidence in bank lending is then at a low. In addition women have been found more likely to view access to finance as a problem and less willing to take on debt (FSB 2012). Evidence from the US and UK shows that many business owners may be discouraged from applying for loans for fear of rejection (F reel at al, 2010) becoming "discouraged borrowers" (K on and Storey, 2003) with women having a higher expectation of being denied a loan and being more discouraged than men(Coleman, 2002). Freel et al (2010) found that al most $24 \%$ of female owned businesses in their sample were discouraged for applying for a loan compared with fewer than $14 \%$ of firms led by a male. R elationships with banks are particularly important for female business owners as women rely more heavily on commercial and personal debt than men (Coleman, 2000; Coleman and Robb, 2009). Y et some research suggests that bank managers assess loan applications and interact with 
female business owners in a discriminatory fashion (Buttner and Rosen, 1992; Fay and W illiams, 1993). There is also evidence of discrimination against women in access to finance (Hashimzade and Roionova, 2013). Bank-business owner relationships vary by gender (Saparito et al., 2012) with male-male pairings showing the highest levels of trust, and satisfaction with credit access while female pairs had the lowest for each measure. It appears questionable whether bank lending is seen as an ethical or fair process and gender may play a part in the judgements being made.

Gender is one of the most frequently studied variables within the ethics literature and a large number of studies find that females are more ethical than males (Dalton and Ortegren, 2011; O'Fallon and B utterfield, 2005). Females make more ethical judgements (Cole and Smith, 1996; Dawson, 1997; Deshpande et al., 2000). Dalton (2011) notes that gender socialization theory may provide some theoretical support for when and why gender differences exist. It posits that females are socialized into more communal principles such as a general concern for well being of others, while males are more socialised into personal growth and aggression. These principles are however not revealed in research on ethical judgements in vignettes. When making ethical judgements about situations in vignettes, research has shown that women are harsher on women than men, and men are harsher on men than women. Subjects are more agreeable to ethical decisions made by a male actor than those made by a female actor (Schminke,1997). There is also research showing similarities in both genders as they process ethical information (Tsalikis and Ortiz-Bonifina, 1990). Both genders rely on utilitarian outcome-based reasons (Schminke, 1997) and share common value hierarchies (Sikula and Costa, 1994). Gender differences are thought to largely depend on the context of the ethical issue under investigation (Dalton and 
Ortegren, 2011). Research has also looked at ethical behaviour in banks, but gender was not a variable (M itchell et al., 1992). This research sets out to examine whether gender plays a part in the judgement and decision making around the granting of business loans by banks using a vignette (a business plan). W ould the gender of the loan officer make a difference and would the gender of the applicant be significant?

In theory a business owner approaching a bank for a business loan might expect that bank business would be "discharged according to calculable rules" and "without regard for persons" (W eber, 1948, p. 215), W eber stresses, in his ideal type of bureaucracy, how a bureaucrat exercises the authority delegated in accordance with impersonal rules; rational legal rules impersonally separate the rules for the person administering them. The "formalistic impersonality" of bureaucratic administration means that everyone "is subject to formal equality of treatment" (1978 V ol. 1, p. 225). However W eber also says that the bureaucrat is professionally and technically qualified to do the job. They are exercising authority delegated to them, and are employed to exercise discretion in each case they deal with. B ank loan officers too, it could be argued, are employed to use their discretion and judgement. A Ithough banks have tried to standardize and routinized the decision process for small loans, commercial loan officers in many banks are not bound by decision rules for larger loans. Even where a scorecard process is being used for small loans, where criteria for a loan decision are set, there is likely to be judgement made and discretion used on whether or not the applicant meets the criteria. The room left for judgement and discretion could mean that unethical judgement and unfair discrimination could be taking place. 
The ideal type of bureaucracy was a construct from a highly specific place and time, and as Courpasson and Clegg (2006) note, it would have been odd for later and different realities to correspond to it. Sociological theory has acknowledged that bureaucratic decisions are not free from judgement and discretion. Weber did not maintain that bureaucratic organizations operate as efficiently as "slot machines" (Bendix, 1966, p. 427). "B ehind every act of purely bureaucratic administration there stands a system of rationally discussable "grounds" (B endix, 1966, p. 428). The "objective" discharge of business without regard to persons entails a trained capacity to treat people as individual cases free from the partialities of patronage and the dangers of corruption. Bank loan officials have been trained to make individual decisions on each loan application, to formulate the grounds for supporting, or rejecting each application using their experience and judgement. Loan officers usually make funding decisions on the basis of information gathered from an interview and a business plan. What then are the grounds on which these loan decisions are made and are they impartial?

\section{Previous Research on F unding Decision C riteria}

There is no set definition of the criteria that are used in bank lending decisions but Jankowicz and Hisrich (1987) claim, "Commercial loan decisions involve both specific, quantifiable information and subjective, qualitative judgements" (1987, p. 45). These are often summarized as the five Cs of commercial lending - character, capacity, capital, collateral and conditions. Intuition or "gut feelings" are involved in these personal judgements as loan officers consider "personal interactions with and assessments of loan applicants when making loan decisions" (Cole et al, 2004: 249). It is not surprising however that research has found that it is the quantifiable financial 
information that is stressed. B anker's funding decisions are dominated by financial considerations, in particular the availability of collateral (Berger and U dell, 1998; M ason and Stark, 2004). They will give little consideration to entrepreneurial capabilities or the characteristics of the opportunity (D eakins and Hussain, 1994; Fletcher, 1995; Storey, 1994). Loan officers are under pressure to generate loan volume to meet bank profit goals ( $\mathrm{M} \mathrm{cN}$ amara and B romiley, 1997). They reach a high level of confidence early in the lending process based on summarized accounting and other general background data (Danos et al., 1989).

A cknowledging the place of feelings in decision making, Lipshitz and Shulimovitz (2007) examined intuition and emotion in bank loan officer's credit decisions. Loan officers noted their impressions and gut feelings regarding the credibility of the loan applicant. Gut feelings were regarded as more valid indicators of application worthiness than financial data. Hisrich and B rush (1986) also report on what a bank loan officer looks for before granting a loan request including for example "experience in the field," and, "confidence and knowledge of the product or service and preparation of a "complete, well-documented loan package" (1986, p. 127). These criteria are immeasurable and subject to pure judgement and discretion on the part of the loan officer. Intuition, emotional, behavioural and cultural factors drive loan officers' assessment of borrower's credit worthiness complementing (sometimes even reversing) information from financial statements (Bellucci et al, 2010a; Buttner and Rosen, 1988; M cN amara and B romily, 1997; Lipshitz and Shulimovitz, 2007); however it is unlikely that decisions will be based only on intuition. It would appear then that there are many variables that influence loan officers. While some of these variables relate to the business, others concern the business owner; all involve 
judgement and discretion. Few of these studies, look at gender as a variable. W hat then does research say about the place of gender in loan decisions?

\section{Gender and Loan Decisions}

There is mixed evidence about gender of applicant and loan decisions. For example Robb and Wolken (2005) found no differences in bank lending practices, approval rates, or credit terms between men-owned and women-owned businesses. However while Fraser (2004) found no significant differences in rejection or discouragement rates by gender, he also found that majority female owned businesses paid significantly higher margins on term loans than male owned businesses ( 2.9 versus 1.9 percentage points over Base); this result was robust when controlling for business and loan characteristics. W omen then do not fare well in judgements made by bank staff about business finance. Similarly Coleman (2000) and A lesini (2008) have found that creditors discriminated against women on the price of loan contracts and face tighter credit availability (B ellucci et al., 2010b). Credit officers have been found to maintain discriminatory attitudes (K ryzanowski and Bertin-B oussu, 1984) while loan officers and bank managers have been accused of treating women in a condescending or discriminatory fashion (Read, 1994; Still and Guerin, 1991). We should not be surprised then when research finds that women are discouraged and are significantly less likely to apply for a loan (Treichel and Scott, 2006). W omen may also be less likely to gain access to bank finance because of the structural characteristics (e.g. sector, size, firm age) they disproportionately exhibit (Orser et al., 2006). H owever structure does not fully explain differences between male and female business owners and there are different emphasis given to certain criteria by male and female lending 
officers. The processes used by male and female lending officers to negotiate loan applications also show differences (Carter et al., 2007).

A $n$ experimental design is clearly needed in order to hold variables constant and to compare results for males and females. Fay and Williams (1993) too used an experimental design sending a business plan, a current and projected profit and loss statement for the business, resume (with a photo of a male or female applicant), personal financial statement, a loan application summary, a brief questionnaire and a covering letter to a random sample of loan officers in 200 bank branches of four major trading banks in towns and cities in New Zealand. The scenarios were identical in all respects except for the sex and education level of the applicants. A multiple-choice question was used to establish whether loan officers would grant finance in full or in part, or would decline the loan. They were asked to provide the reasons for their decision, and to complete a rating scale to ascertain those factors that were important to the decision. Fay and W illiams found that there was no significant difference in the proportion of female and male applicants who were judged acceptable for loan finance if they had a university qualification. How ever if the university qualification was absent there was a significant difference in the probability of being granted a loan in favour of the male applicant. L oan officers rejecting the female applicant were more likely to say that they the female applicant lacked sufficient equity/security despite the fact that the level of equity and all other variables were identical for male and female applicants. This research then demonstrated experimentally that some loan officers do employ differing evaluative criteria for female and male applicants and that "these differences in evaluative criteria may act to female disadvantage" (Fay and Williams, 1993:304). 
Female business owners report that they have difficulty obtaining capital for their businesses (Hisrich and B rush, 1984). Hisrich and B rush (1984) found that of 468 women entrepreneurs, the biggest problems during start up were lack of business and financial training, obtaining credit and lack of collateral. M any of the women had not established credit ratings making it difficult to obtain conventional financing. W omen business owners al so report that they experience discrimination from banks. Fabowale et al (1995) found that women were more likely than men to perceive that they are not given due respect by financial institutions, that they did not think that their account managers were easy to talk to, and that they were more likely to report they were not made to feel comfortable by financial institutions. In a W omen in Business Finance Survey, $21 \%$ of women said they had experienced discrimination (M asterton, 2005). These findings may help explain why women business owners tend to express feelings of gender bias. Perhaps this is why companies owned by women use less external finance, including bank debt, than men. While men raise around $70 \%$ of their business finance through banks and other external sources, women raise only $30 \%$ preferring to rely on savings and family loans rather than approach a bank ( $M$ asterton, 2005). W omen also report that face discrimination in starting and operating their businesses (Hisrich and B rush, 1986). Banks can give women the impression that they should not be operating a business (Hisrich and O'B rien, 1982). Questions then are raised regarding the degree to which bank loan officers would be influenced by sex role stereotypes when considering loan applications from male and female business owners. 


\section{C ritique of previous research and rationale for this research}

Some of the research does not compare the experiences of male and female business owners or the views of bank loan officers judging applications from both male and female business owners. There needs to be matched samples of men and women for this research. All rel evant factors up to the point of the loan application, and the loan application itself, need to be equalised.

In the research from the bank's perspective UIrich and A rlow's (1981) questionnaire survey of 128 commercial loan officers provided a list of 30 possible variables from which loan officers could choose those which most affected their decisions about loan applications. This method "cues" research participants of the variables that might be important in a fair and just decision. The photo in Fay and W illiams's (1993) experiment may well have affected the loan decision rather than the proposal itself. Danos et al. (1989) looked at the impact of accounting information on the judgement using cases, where variables were manipulated.

M uch of the research is based in contrived laboratory conditions. M uch is based on decisions arising from vignettes which focus simply on the gender of the actor and not also on the process of the decision making. $V$ erbal Protocols gather richer data that questionnaires. It is clear that subjectivity and judgement are involved in the loan decision, but we are no wiser on how much of any one variable is needed for a positive decision, for example how much management experience is required. Previous research has so far failed to examine the logic and flow of the decision as it is being made. We need to examine day-to-day decision-making on loans and how 
gender may, or may not, play a part in order to gain greater insight into the loan decision process and whether or not discrimination against women is taking place.

\section{Research Setting and Design}

This research set out to examine the process and criteria used in loan decisions. We wanted to know about the loan process, loan criteria and the loan decision. Did the gender of the applicant or loan officer make a difference? Would there be ethical decision making and equity in process of loan decision making?

The research was conducted by a research team with the support of a major UK Clearing Bank. Just $11 \%$ of corporate managers and senior executives in banking are women (EHRC, 2009). In a recent survey (Institute of Leadership and M anagement (2012) it was found that fewer than one in 10 women (9\%) occupied senior and executive roles, compared to $21 \%$ of men. The lack of women at the top of the sector has led one bank chief executive to describe the banking industry as "pale, male and stale." (Treanor, 2013). In common with other major UK Clearing Banks, we found that this bank employed similar low levels of female senior managers. The bank had recruited a new tier of 350 lending staff, and a sample was drawn from these lending officers for our study. A s these loan officers had all been employed by the bank in the same occupational position at the same time, they shared a broadly similar frame of organizational experience and this minimized possible bias resulting from variations between individuals in organizational experience and knowledge.

Data were collected in the bank's offices in four cities to see if there were different practices to be found in different cities. We expected the practices to be homogeneous 
across cities and this proved to be the case. In the first stage interviews were carried out by the research team with seven key individuals in senior management, above loan officer level, to gain an understanding of how they described how bank lending was done, in particular the procedures for lending and the criteria. They were informed that this was an "academic study of lending practices" and assured of confidentiality and anonymity. (To preserve anonymity, all research participants' names have been changed). Interviews were about an hour long.

For the second stage thirty-five bank-lending officers (19 female and 16 male) were interviewed in the four cities by the research team using exactly the same format of questions. A s one of the aims of the research was to see if the judgements about a fictional loan applicant differed if the applicant was male or female, the loan officers were given a fictional business loan application, which replicated the four page experimental procedure developed by Fay and W illiams (1993). Only small details of the fictional business loan application were changed in the case to reflect the national context, for example the currency signs were substituted as well as the home address and applicant's university. L oan officers were given loan applications that were identical except for the sex of the applicant; the sex of the applicant was identified by use of a first name. The names given to the applicants were E mma or J ack J ones, selected because they were the most popular first names in the country in the year preceding this study. Ten male loan officers judged the application from J ack while 6 judged the same application from Emma. Eleven female loan officers judged the application from Emma while 8 judged the same application from J ack. 
The loan officers were individually asked to read and then articulate their reactions to the application, the criteria they were considering, and their loan decision. This technique is now well established in studies investigating decision making of business angels and investors (M ason and Rogers, 1997; M ason and Stark, 2004). Each interview lasted up to thirty minutes. Interviews were tape recorded and transcribed.

In a third stage, bank-lending officers participated in one of six focus group discussions of lending criteria and processes. $M$ ale and female groups were seen on separate occasions; three groups were all male and three all female. They were asked if the business plan they had considered would be a plan they would consider lending to and questions such as what was good about this plan that made it attractive for lending and what would a quality deal look like. They were also asked to more fully discuss the proposal from Emma or J ack. (Table 1 here)

To control moderator bias, the moderator was the same sex (female) for all six groups. This was to ensure that changing the gender of the moderator would not influence group response. The questions for the group focussed on their understanding and interpretation of the bank's lending criteria, the characteristics they favoured in loan applicants and the procedures they followed in proposing loan applications for credit sanctioning and bank approval. The focus group discussions were also tape-recorded and transcribed.

\section{Analysis of data}

The 7 interviews with senior managers and the 6 focus groups were analysed using the research questions as a template or guide and using N vivo software. What was the 
process of lending, and what criteria were being used? From this we would be able to see if there was room for discrimination on the basis of gender.

The transcripts of the individual interviews with the bank loan officers were independently analysed by three research team members. Two used N vivo software while the third used a manual procedure using coding and word processing to aid the analysis. In the manual procedure the individual interviews were simply analysed for the constructs that related to positive or negative judgements being made about the person (J ack or Emma), or the business plan. The interviews were also analysed for further questions and information the respondents would ask of the loan applicant. The final decision for each interviewee was also recorded.

The two Nvivo analyses, independently coded, demonstrated converging results. The advantage of the N vivo coding and analysis was that it showed how many criteria were being used and the how many times the various criteria were discussed in the interviews.

\section{Findings from $1^{\text {st }}$ stage interviews with senior managers}

\section{Lending decisions: the process}

The seven first stage interviews, at senior management level, revealed that the bank lent to all sectors. Small value proposals went through a scorecard procedure. Information was put in a computer and a decision given. 
There are different processes for existing and new business customers. For existing customers the scorecard method is used and if the customer passes and the loan is below or between $£ 50-100,000$ then the sales person has the discretion to make the loan. If the loan is for a greater amount or the scorecard wants more information, then a more in depth analysis is undertaken by the same person. They might ask about strategy, key strengths, what forces impact on this, and other factors.

A lending team in one of the cities where we interviewed reveal ed certain procedures that were followed in the lending process. For example loan officers should find out why the business owner needs the loan, and the amount of loan. They should see about 3 year's of business accounts, do anti-laundering checks, and acquire solicitors' and independent financial advisor reports. A bout $80 \%$ of their customers come through personal contacts and the "introducer network" such as solicitors and accountants.

\section{The lending process: the criteria}

First stage interviews with the seven senior managers revealed that in this bank there are "no rules," no set criteria or set standard for making a loan decision, so discretion and judgement is being exercised in loan decision-making. Nor is there training. The criteria described as "crucial" in assessing the application included personal characteristics (age, work experience, education), right attitude and personal contact/network. $Y$ et if there are no guidelines, rules or criteria how does the lender or applicant know if they are the "right" age, the right attitude or have the relevant work experience or educational background? J udgement, experience and intuition help make up the evaluation - decisions such as "A re these people I can work with?" "Is 
that person really interested in that business or are they just going to waste your time?" "Feelings are important" (Paul). The applicant's CV is important. Only "broad brush" criteria are used. Perhaps only one in ten applications might get through the initial application stage. The bank loan officers however do not make the final decision; a recommendation is made to a credit committee or a credit sanctioner.

A ccording to Paul, the important criteria in the lending decision would be product, market place/industry, price of business they are buying, assets, how much they are putting into the business, historical record and confidence in the management team. While these were all important he also said that it "all depends", it's the "combination that makes it tick" and that there are certain types of business that he personally is not interested in.

Two of the senior managers (Paul and Rachel) emphasised the importance of their experience and individual judgements in making their decisions. The bank Ioan officers are exercising authority delegated to them and discretion. They can make a recommendation without meeting the person. The source of the initial contact (if through an internal referral for example) can also make a difference to how positively or negatively the application is viewed. J udgement is made about the person introducing the business and their "calibre" or if the applicant is "well known". "But some people you meet, you just, no, you know you get that feeling; you don't want to do business with these people". "So no matter how good the deal is, my view is, walk away. Y ou can quite often do that by pricing" (Paul). 


\section{The perception of possible gender discrimination}

The bank did not have data on numbers of men and women approaching the bank for loans, or the number of loans given to men and women business owners. There was awareness though within the bank that there was a problem of perceived equity in terms of loans. The bank had sponsored and conducted a survey that focused on women's confidence in financial products. They found that women were not confident about formal business products and 24 of the 150 women (16\%) reported that they had experienced discrimination in their dealings with banks.

One of the senior managers (A ileen) acknowledged that there may be "some unconscious discrimination" in the scorecard procedure. Proposals for business loans were scored on characteristics and it was possible that these characteristics, why they are used, and how they are scored could be a source of discrimination. The first impressions of loan applicants could also be a source of discrimination (R olf). Experience and financial awareness will be factors that are judged. There were "cannons" of lending but the researchers did not see what these were.

One of the senior female managers we interviewed (K irsten) acknowledged that women perceive barriers to accessing bank finance and it is "really endemic". B oth K irsten and another senior female manager (A ileen) talked about an "unconscious bias" that they feel may exist towards the female small business owner. Both K irsten and $\mathrm{A}$ ileen felt that there are problems at the first stage, problems in the interaction between the (probably male) relationship manager and female business owner. Aileen could see that she could feel patronised going into a bank and the (male) manager 
might think that they have to treat the woman differently. There is a danger then in treating women differently that they feel patronised. The problem of bias, as Aileen sees it, may lie in this issue of male to female communication, the psychology of the interaction with men and women, and women being patronised. The issue may also be about the nature of the business proposal that a woman would put forward. R olf felt that women customers may be emphasise the risk more and bring that to the bank's attention.

\section{Findings from $2^{\text {nd }}$ stage interviews with the individual bank loan officers}

L oan officers said there are no set criteria being used in the loan decision. Their personal experience and judgement was used to the full in deciding what was positive about the loan application, what else they needed to know and how secure they felt the loan would be. There were al most no negative statements made about the business proposal or the person.

N vivo analysis showed a wide variety of criteria being used to assess loan applications. Forty four criteria codes were derived from the verbal protocol analysis. These were then grouped into five core codes: 1) the personal characteristics of the

applicant, 2) the terms of the loan 3) the characteristics of the business 4) assumptions about the written plan made by the loan officers and 5) requests for further information. Eighteen criteria codes accounted for $83 \%$ of the coded output with the remaining 26 criteria codes each accounting for less than $1 \%$ of output. The loan applicant's financial status was the most dense criteria code occupying $10.5 \%$ of total text output. (Code density calculates the percentage of text characters that respondents spend talking about the theme or code). The decision was not then being made purely 
on the financial information presented in the business proposal. Facts about the individual and their circumstances came into play. There appeared to be no systematic way in which individuals analyzed or scrutinized the business proposal. They all went about it in different ways using a mixture of the 44 criteria identified by the analysis, and judgments, before making their decision on whether or not they would lend.

W as the loan to be granted to J ack or Emma and did gender make a difference? The sex of the applicant was rarely mentioned; this criteria code occupied only $0.04 \%$ of dialogue, was ranked lowest out of the 44 criteria codes in terms of density and only four of the identified criteria showed statistically significant differences by sex of the Ioan of the applicant, a number which is hardly greater than would have been expected to occur by chance. What about the decision to lend to the male versus the female applicant? The female loan officers were more reserved in their judgment than the males. Five of the females and one male gave no overall decision. Those males and females who did give a decision about J ack or Emma were positive; gender was not used to discriminate. The key judgement appeared to be whether or not the business was perceived as viable, so producing enough cash to make repayments for the loan, and whether there was enough security to make it a safe deal. These appeared to be the two main judgements in use.

One very striking finding came from the initial manual procedure of coding and analysis of this qualitative data. The simplest initial manual coding system was to sort the data into positive or negative judgements about J ack and Emma's loan proposals. All the data from the individual interviews was coded and sorted into either positive or negative statements about either the proposal or the person. There was also an 
analysis of final decision whether or not they would lend to J ack and E mma. It was found that there was no direct relation between number of positive statements made and final decision. For example one female judging Emma's proposal made 16 positive statements and no negative but the final decision was luke-warm " $\mathrm{H}$ appy to look at this proposal and consider it".

\section{Findings from $3^{\text {rd }}$ stage focus group interviews with the bank loan officers}

For the focus groups, participants were informed that the research was about how banks take lending decisions and the criteria used in those decisions. They were first asked if the business plan would be a plan they would consider lending to. The answer from three of the groups was positive; two involved J ack and one Emma. However two women's groups (one judging J ack and the other Emma) started off with more cautious answers one saying they would want to discuss security first. The sixth male group did not actually answer the question directly, but some of them at least had a positive view of J ack's business plan. For one male focus group judging J ack it was assumed he would be a "hands on" manager. This assumption led to another, that he wants this business venture to work. They also liked the fact that they judged he was "averse" to debt.

M uch of the discussion focussed around the additional information they would want to see. Examples included three years of accounts, a monthly breakdown of income and expenditure and more information on the lease, while one group would have liked to meet the proposer to find out more about their experience and training and whether 
or not they were going to be "hands on" with the business. Two groups wanted to know about the applicant's previous experience. One group would have liked more details on sales and customers while another would have wanted to have tested whether or not the accounts were "credible" and had come from a "credible accountant", to see how the assets were set up, the reasons why the existing owner is leaving, how successful previous businesses in that location had been and what the applicant's future aspirations were for the business. It became clear then that they would all ask for different additional information. They were not all working to the same standard set of criteria.

What criteria are laid down by the bank for lending decisions? The focus groups said that they didn't really get criteria. One male group mentioned viability and security while another said it was "open book". This made them different from other banks. Other banks did have set criteria. This bank was described as "much more flexible" as Ioan officers could check a potential deal with credit before structuring that deal. The Ioan officers argued that they did the analysis themselves, "so you build the structure and transaction yourself, rather than actually put it into a framework that's al ready been laid down by a bank" There are however "broad parameters that you know". For example "Y ou know you are a not going to get a $90 \%$ loan to bank through unless there's exceptional circumstances but you know those broad parameters... " One problem was that the credit sanctioners were not al ways giving them enough information on what deals they wanted to see, so the loan officers were unsure if the credit sanctioners were using criteria for loan decisions that the loan officers did not know about. 
What are the criteria they would first consider when looking at a loan application. One group said they were taught the "basics". These were "the purpose of the loan, the amount, how they are going to pay it - over what period and what security's available." A t its most fundamental, you needed to know if the company had the ability to repay the debt. This may mean you needed test the assumptions in the figures and ask questions like, for example, "how many units do you have sell at what price to generate that level of cash, and what are the competitors doing, who is the management team, how big is the market".

There is no guideline that says how much security, financial viability, or any criteria, is sufficient in any one set of circumstances so inconsistency in decisions can arise. A s one female explained: "L ending is not black and white. There are guidelines, yes, but it's basically that I could look at a proposal and decline it and security could approve it. Y ou're going to get that all over the bank - hopefully not too often". A male in another group too recognized that decisions from credit sanctioners could be inconsistent. "Y ou may get the same proposal, for one sanctioner he' II just say yes I'll do it, for other sanctioner we say yes I'II do it but I'Il do it at a reduced level. A nd I think that creates an issue for everybody in the deal because it appears the sanctioners can be very inconsistent".

The loan officers could see why there were no criteria: "Every case that we get, you know, this is individual". There are no two cases alike. For example you could have a proposal for a restaurant to be set up in a tourist town and another for a similar restaurant in a poor area. Each had to be viewed on their own merit. 
The issue of whether there should be guidelines for loan officers to guide them on the kind of deals and sectors that credit might be interested in sanctioning, exercised the loan officers. They would have liked to know if credit had "an appetite" for certain deals. But they also argued that they did not want the lending decision or criteria to be objective or scientific:

“W ell you don't want to make it to scientific, so you don't need me then because it ticks all the boxes, you don't need an independent eye to look at it. It would be just a rubber stamp. It would be score card and tick box lending". The absence of policy and credit policy guidelines makes the job of both loan officer and credit sanctioner more difficult.

What criteria do they look for? Experience is one of the key criteria and was mentioned for example 8 times one focus group and six times in another. They also look at the person's track record, the sector and the performance in that sector (although it is recognised that there are companies that perform well in "bad" sectors). They look at the financial contribution the business owner will make and assess the potential for the business "going forward" and developing. They are also interested to see if the business owner has done a risk assessment and if they see the risks in their plans. How are they going to cover those risks? They say they look at the "viability" of the company. What is viability? It involves looking at the finances and assessing if the management team is strong, do they know what they are doing with the business and are their plans realistic? They al so get a feel for how well the business owner is able to answer their questions. Do they really know what they are talking about, do they have the figures to hand, have they prepared them or been involved in their preparation or has an accountant prepared them alone? Do they know where the 
figures have come from? How knowledgeable are they about the business and of the sector. If you visit you will get a feel how the business is organized, how well it is run, how the business owner interacts with the staff, whether the business owner has a good team behind them and the morale of the workforce. While this might not affect your lending decision it will "help tick boxes" for you - e.g. they will not loose staff and have health and safety issues covered.

J udgements have to be made by those making decisions about loans, for example on whether the business owner is good at putting a business plan together, what information is missing. For example do they know the competition and market, what skills and knowledge do they have? So the interview is useful for extracting that information. Y ou can also see how enthusiastic they are, whether you feel they are astute or whether they are committed enough to make the business succeed and want to offer security or just the bare minimum. A n interview might reveal whether an accountant or someone else had prepared the business plan in order to secure a loan.

When discussing criteria in one group, one said the loan officers started "In nine times of ten it boils down to the people... you know when you see them. So you might get an impression on paper but it can swing it one way or another when you actually meet them".

It is clear then that much of the impression of the business owner is gathered on meeting them or talking on the telephone. They al so discussed the "key person situation", had the business owner assessed what would happen if they or a key person fell ill, or died, or was incapacitated in some way. 
Did they sometimes find that the impression gained from the proposal on paper was different to that gained when meeting with the loan applicant? Here is how one woman described the experience: "A nd you al so get occasions when, you know it looks great on paper and you meet the guy and you'll be lucky sometimes if he add two plus two never mind, you know, going into a business - you do get that kind of thing, you know, not very often but you do get things were the broker's really set it up and he's done all the information or the accountant's done everything and you go along and you know they don't know what they're talking about"

Gut feeling was discussed quite a lot as an integral part of the lending decision. When a female focus group were asked what gut feeling was, they said it was about how keen the applicant was about what they were doing, how willing they were to put in a lot of time, money and effort before applying for the loan; it was also about having a good understanding of what they want to do and still have to do and whether they are working with you. But a group of men had gut feeling as a criteria for lending "F rom meeting the guy you are going to get a feeling for his, you know ..." "It's your gut instinct". "Y eah, the CV can tell you whatever it wants to tell you. Y ou can't check it, not that you are mistrusting people, but you are going to meet the guy and see what he says and you are going to have a gut instinct ... " A nother male group talked about trusting the person and valuing what they are trying to achieve. They would look at body language and see whether or not they have to ask the same question three or four times. "The acid test is, may be, would you put your own money into this? If the answer is no, then why should you put the bank's money in?" When meeting the 
person, a third male group were able to add to this list of criteria - How confident do you feel about the applicant? Does he have charm and charisma? Do you feel comfortable with him? So the impression from the client can affect the judgement about whether or not to lend.

M eeting the person, talking further and "digging deeper" with questions about their level of commitment, about the reasons for the loan and whether or not you feel you can trust them are actions which the loan officers find easy to justify. W ritten information such as CV's or business plans will only contain positive information. They admitted that decisions were subjective, particularly if you had had a bad experience in a sector before or were influenced by a newspaper report about businesses in a certain sector failing. Further, while they claimed in focus groups that education and qualifications don't count, 13 of 34 individuals in interview commented favourably on fact that the loan applicant had a degree. It was also found that some positive judgements led to others e.g. J ack was judged as having lots of personal assets behind him so "he's obviously somebody who's worked hard for what he has"

\section{Conclusions}

In this study we have looked at the consequences of gender on the criteria and processes used in bank lending decisions with a specific focus on the sex of the bank Ioan officer. The results of this study support the findings of Fay and W illiams (1993) in that the gender of the applicant made little difference to the lending decision. The gender of the loan officer also made no difference so gender socialization theory remains unsupported in the results of this study. It could be argued then that the loan officers are "good bureaucrats" who do not discriminate against women. However 
when we start to look more deeply at the process of lending, plenty of room for discrimination is found.

The bank does not lay down rules or criteria but expects the loan officer to make judgments in each case on whether or not to support the loan proposal. The good loan officer is not a "good bureaucrat" who adheres to standards of impersonality. Criteria are not impersonal. J udgment is being exercised and that judgment could be based on assumptions, gut feeling or intuition. This is what the sociological theory literature on bureaucracy fails to warn us about. Even scorecard procedures, the most bureaucratic of loan decision procedures, have been found by this research to be a potential source of gender discrimination. Quantifiable financial information requires judgment, for example how much collateral is sufficient in any situation. It is in this judgment that disagreement could arise between bank loan officer and where there is room for discrimination against women to be occurring, for example if a female loan applicant is not perceived as running an "exciting" business, experienced or confident enough. This kind of discrimination is unlikely to be uncovered or identified as gender discrimination. Discrimination is more likely to be perceived as gender discrimination if women are asked to pay higher margins in term loans or report that they feel they are or will be discriminated against.

Whilst not monitoring the number of loans granted to male and female applicants, consciously or unconsciously discriminating against women, the loan officers work within broad parameters and know broadly what the credit sanctioners and the bank are likely to support. They can see why it is the case that they make the judgments. The bank does not want to be seen as "tick box" and mechanical in its decision- 
making. It is trying to establish a reputation for being flexible and doing deals that other banks may not do. There are many variables at play, for example the size of the Ioan and the contribution the business owner is going to make. It may be that the potential business owner is not good at producing a business plan but may give a better impression in a face-to-face interview. The impression formed by the loan officer of the loan applicant can be crucial to the decision. Gut feelings and intuition are so prominent in the decision on whether or not to lend that however good the deal, the loan officer can still decline the deal if their gut feelings or intuition dictate. Early research, and this research, showed how subjective qualitative judgement was required to make loan decisions. Perhaps the finding that intuition and "gut feeling" is important in the decision whether or not to lend is not surprising if you know that General Electric's retired CEO, Jack W elch calls his memoir "J ack: Straight from the Gut" (2001). Gut feeling has al so been found to play an important role in investment decisions in small firms (Ekanem and Smallbone, 2007). Gut feeling expresses how you feel. It is more difficult to say why you feel that way (Gladwell, 2005). That information is "behind the locked door". While managers admit to a wide use of intuition and regard it as valuable in their decision-making, some writers have regarded it as a source of error (e.g. B onabeau, 2003). This paper would argue that it is a source of potential gender discrimination and unethical decision making.

Research on gender discrimination or prejudice is always difficult because it is socially unacceptable, counter to organizational policy and illegal. A ny investigation is going to be constrained by these factors. No bank or any other organization is likely to openly admit to discriminatory and unethical business practices. It is not possible to conclude that in this case the bank definitively discriminates against women business 
owners. However the evidence does point to how it may be discriminating, why women business owners may perceive banks to be discriminating against women, and where there is space in the loan decision criteria and process for discrimination to happen. Unless banks collect and analyse their data on loans granted to male versus female applicants to demonstrate that they are making ethical, non discriminatory decisions, there is room to accuse them of unethical decision making. Future research should be orientated towards the challenge of better understanding why this process of bank loan decision making is failing women.

\section{References:}

A lesini, A., Lotti, F. and M istrulli, P.E. (2008) Do women pay more for credit?

Evidence from Italy, W orking Paper, NBER.

Bellucci, a., Borisov, A., and Zazzao, A . (2010a) Do male and female loan officers differ in small business lending? A review of the literature, M OFIR W orking Paper no 47, N ovember.

Bellucci, a., B orisov, A., and Zazzao, A . (2010b) Does gender matter in bank-firm relationships? Evidence from small business lending, J ournal of B anking and Finance, 34, 2968-2984.

Bendix, R. (1966) Max Weber: an intellectual portrait, University Paperbacks, M ethuen, London.

Berger, A.N . and Udell, G.GF. (1998) The economics of small business finance: the role of private equity and debt markets in the financial growth cycle, J ournal of Banking and Finance, 22, (6-8) 613-673.

Bonabeau, E. (2003) Don't trust your gut, Harvard Business Review, 5,116-123. 
Buttner, E.H. and Rosen, B. (1988) Bank loan officers' perceptions of the characteristics of men, women, and successful entrepreneurs, J ournal of Business Venturing, 3, 249-258.

Buttner, E.H. and Rosen, B. (1989) Funding new business ventures: are decision makers biased against women entrepreneurs? J ournal of Business Venturing, 4, 249261.

Buttner, E.H. and Rosen, B. (1992) Rejection in the loan application process; male and female entrepreneurs' perception and subsequent intentions, J ournal of Small Business M anagement, 30, 58-65.

Carter, S., Shaw, E., Lam, W. and W ilson, F. (2007) Gender, entrepreneurship and bank lending: the criteria and processes used by bank loan officers in assessing applications, Entrepreneurship, Theory and Practice, 31, 427-444.

Cole, B.C. and Smith, D.L. (1996) Perceptions of B usiness Ethics: students vs. business people, J ournal of Business Ethics, 15, 8, 889-896.

Cole, R., Goldberg, L and W hite, L (2004) Cookie cutter vs. character: the micro structure of small business lending by large and small banks, J ournal of Financial and Quantitative Analysis, 39, 227-251.

Coleman, S. (2000) A ccess to capital and terms of credit: a comparison of men and women-owned small business, J ournal of Small Business M anagement, 38, 37-52. Coleman, S. (2002) Characteristics and borrowing behaviour or small women-owned firms: evidence from the 1998 survey of small business finances, J ournal of Business and Entrepreneurship, 14, 2, 151-166.

Courpasson, D. and Clegg, S. (2006) Dissolving the Iron Cages: Tocqueville, M ichels, Bureaucracy and the perpetuation of elite power, Organization, 13, 319-343. 
Dalton, D. and Ortegren, M . (2011) Gender differences in ethics research: the importance of controlling for the social desirability response bias, J ournal of Business Ethics, 103, 73-93.

Danos, P., Holt, D.L., Imhoff, E.A. (1989) The use of accounting information in bank lending decisions, Accounting, Organizations and Society, 14, 3, 235-246.

Dawson, L.M . (1997) Ethical differences between men and women in the sales profession, J ournal of Business E thics, 16, 11, 1143-1152.

Deakins, D. and Hussain, G. (1994) Risk assessment and asymmetric information, J ournal of Bank Marketing, 12, 1, 24-31.

Deshpande, S.P., J oseph, J ., and Prasad, R. (2006) Factors impacting on ethical behaviour in hospitals, J ournal of Business Ethics, 69, 207-216.

Equality and Human Rights Commission (2009) Employment and earnings in the finance sector: A gender analysis.

Ekanem, I. and Smallbone, D. (2007) Learning in small firms: the case of investment decision making behaviour, International Small Business J ournal, 25, 2, 107-129. Fabowale, L., Orser, B. and Riding, A . (1995) Gender, structural factors, and credit terms between Canadian small businesses and financial institutions, Entrepreneurship, Theory and Practice, Summer, 41-65.

Fay, M . and Williams, L. (1993) Gender Bias and the A vailability of Business Loans, J ournal of Business Venturing, 8, 363-376.

Free, M ., Carter, S., Tagg, S. and M ason, C. (2010) The latent demand for bank debt: characterizing "discouraged borrowers", Small Business E conomics, found at http://www.springerlink.com/content/lut2167g10105672/ (FSB ) Federation of Small Businesses, Entrepreneurship Inquiry will tackle access to finance to small firms, FSB N ews R elease, $8^{\text {th }}$ February. 
Fletcher, M . (1995) Decision making by Scottish bank managers, International J ournal of Entrepreneurial Behavior and Research, 1, 2, 37-53.

Fraser, S. (2004) Finance for Small and M edium-Sized Enterprises: a report on the 2004 UK survey of SME finances, Centre for Small and M edium Sized Enterprises, W arwick Business School, W arwick.

Gladwell, M. (2005) Blink: the power of thinking without thinking, Penguin B ooks, London.

Hashimzade, N. and Rodionova, Y . (2013) Gender bias in access to finance, occupational choice and business performance, E conomic Papers, Department of Economics, U niversity of Reading.

Hisrich, R.D. and B rush, C. (1984) The W oman Entrepreneur, M anagement skills and business problems, J ournal of Small Business Management, January, 30-37.

Hisrich, R. and B rush, C.G. (1986) The Woman Entrepreneur, Lexington M A, Lexington B ooks.

Institute of L eadership and M anagement (2012) W omen in Banking, Institute of L eadership and M anagement: London. A vailable at: https://www.i-Im.com/ /media/IL M \%20W ebsite/D ownloads/Insight/Reports_from_IL M_website/Re search_womeninbanking_march12\%20pdf.ashx Jankowicz, A.D. and Hisrich, R.D. (1987) Intuition in small business lending decisions, J ournal of Small Business M anagement, July, 45-52.

K on, Y . and storey, D.J. (2003) A theory of discouraged borrowers, Small Business Economics, 21, 37-49.

Kryzanowski, L. and Bertin-B oussu, E. (1984) Equal A ccess to Credit: lender's attitudes toward an applicant's sex and marital status, International J ournal of Woman's Studies, 4, 3, 13-23 
Lipshitz, R. and Shulimovitz, N. (2007) Intuition and emotion in bank loan officers' credit decisions, J ournal of Cognitive Engineering and Decision Making, 1, 212-233. M ason, C. and Stark, M. (2004). W hat do Investors Look For in a Business Plan? A Comparison of the Investment Criteria of Bankers, V enture Capitalists and Business A ngels, International Small Business J ournal, 22, 3, 227-246.

Mason, C. and Rogers, A. (1997) The Business Angel's Investment Decision: an exploratory analysis in D. Deakins, P. J ennings and C. M ason (eds.) Entrepreneurship in the 1990s, pp29-46, Paul Chapman Publishing, London.

M asterton, V. (2005) Learning to Love Debt, Big Fish, Bank of Scotland, Issue 5, Spring.

M cNamara, G and Bromiley, P. (1997) Decision making in an organizational setting: cognitive and organizational influences on risk assessment in commercial lending, Academy of M anagement J ournal, 40, 5, 1063-1088.

M itchell, W.J., Lewis, P.V. and Reinsch, N.L. (1992) Bank ethics: an exploratory study of ethical behaviours and perceptions in small, local banks, J ournal of Business Ethics, 11, 197-205.

O'Fallon, M.J. and Butterfield, K.D. (2005) A Review of the empirical ethical decision-making literature 1996-2003, J ournal of Business E thics, 59, 375-413.

Orser, B., Riding, A. and M anley, K. (2006) Women entrepreneurs and financial capital, Entrepreneurship, Theory and Practice, 30, 643-665.

Read, L. (1994) Raising bank finance: a comparative study of the experiences of male and female business owners, V enture Finance W orking Paper, 11, N ovember. Dept of Geography, University of Southampton, Southampton.

Robb, A . and W olken, J. (2005) Firm, owner and financing characteristics: differences between female and male owned businesses, W orking paper presented at 
the University of North Carolina B oot Camp on W omen and M inority Entrepreneurship R esearch, A ugust.

Saparito, P., Elam, A . and B rush, C. (2012) Bank-firm relationships: do perceptions vary by gender? Entrepreneurship, Theory and Practice, 1042-2587.

Schminke, M . (1997) Gender differences in ethical frameworks and evaluation of others, Choices in Ethical Dilemmas, J ournal of Business Ethics, 16, 1, 55-65.

Sikula, A . and Costa, A.D. (1994) A re women more ethical than men? J ournal of Business Ethics $13,11,859-871$

Still, L. and Guerin, C.D. (1991) B arriers facing self-employed women: the A ustralian experience, Women in Management Review and Abstracts, 6, 6, 3-8.

Storey, D.J . (1994) N ew firm growth and bank financing, Small Business Economics, $6,2,139-150$.

Treanor, J. (2013) HSBC chief bemoans lack of women among banking elite, Guadian, Friday 8th N ovember.

Tsalikis, J . and Ortiz-Buonafina, M . (1990) Ethical beliefs. Differences of males and females, J ournal of Business E thics, 9, 509-518.

Treichel, M .Z. and Scott, J .A . (2006) W omen-owned businesses and access to bank credit: evidence from three surveys since 1987, Venture Capital, 8, 1, 51-67. W eber, M . (1948). 'Bureaucracy'. Chapter V III in H.H. Gerth and C. W right M ills (eds. and trans.). F rom M ax Weber: essays in Sociology, pp196-244 published as 1991 edition, R outledge: London.

W eber, M . (1978) E conomy and Society, vol. 1, University of California Press, LoS A ngeles, California.

W elch, J. (2001) Straight from the G ut (with J ohn A. B yrne) W arner B usiness B ooks 
Table 1

\begin{tabular}{|l|l|l|l|}
\hline Focus G roups & $\begin{array}{l}\text { M ale loan officer } \\
\text { groups }\end{array}$ & $\begin{array}{l}\text { Female loan officer } \\
\text { groups }\end{array}$ & Totals \\
\hline Judging Emma & 1 & 2 & 3 \\
\hline Judging Jack & 2 & 1 & 3 \\
\hline Totals & 3 & 3 & 6 \\
\hline
\end{tabular}

The author would like to acknowledge the assistance of Professors Sara Carter, Eleanor Shaw and Dr Wing Lam in the collection of the data; they were also researchers on this project. The research team are grateful for the financial support for this project for the Economic and Social Research Council, UK. (A ward reference no RES-000-23-0247)

The final publication is available at Springer via http://dx.doi.org/D OI: 10.1007/s10551-014-2515-y 